УДК 316.728

Лапіна Вікторія Вікторівна

кандидат соиіологічних наук, доктор філософії в галузі соціальної психологї̈, Київський національний університет імені Тараса Шевченка,

Київ, Україна, v.lapina39@ukr.net

\title{
ДИСФУНКЦІОНАЛЬНИЙ ВПЛИВ РЕКЛАМНО-ІНФОРМАЦІЙНОЇ ДІЯЛЬНОСТІ В СУЧАСНОМУ ЄВРОПЕЙСЬКОМУ ПРОСТОРІ: ПРАВОВІ ТА СОЦІАЛЬНІ ЧИННИКИ
}

У статті аргументована важливість соціологічного дослідження дисфункціонального впливу рекламно-інформаційної діяльності в сучасному європейському просторі. На сучасному етапі розвитку суспільств Європи та світу рекламно-інформаційна діяльність значно еволюціонувала як форма соціальної комунікації. Від простої функції просування товарів і послуг рекламна діяльність перетворилася в могутню індустрію та проникла в усі основоположні онтологічні механізми організації суспільного життя. На поч. XXI ст. реклама отримала ознаки рекламно-інформаційної діяльності та стала важливим функціональним компонентом сучасного інформаційного середовища. На думку вчених-суспільствознавців, у глобалізованому суспільстві спостерігається значне посилення глобалізації рекламних практик, зростає прямий i прихований інституціональний вплив реклами на різні аспекти життєдіяльності індивідуальних та колективних суб'єктів суспільного життя. Вочевидь, що глобальна поширеність реклами, іï̈ прогресуюча інтернаціоналізація та безпосередня причетність до інноваційних інформаційних технологій слугують важливими пізнавальними стимулами для перегляду усталених традиційних поглядів на рекламно-інформаційну діяльність. Враховуючи зазначені обставини, мета статті - охарактеризувати соціальнокомунікативні прояви рекламно-інформаційної діяльності в сучасному європейському просторі та визначити особливості дисфункціонального впливу реклами в аспектах ідентифікації правових та соціальних регулятивних чинників цього впливу. У рамках даної статті аргументовані висновки, що сучасні наукові тенденції спрямовані на наукове розуміння реклами в більш широкому контексті ii осмислення, а саме: як інформаційно-рекламної діяльності, яка чинить як конструктивний, так і деструктивний вплив на процеси конструювання певних життєвих стилів індивідів та соціальних груп. Також доведено, що сучасна інтенсифікація процесу глобалізації є тим важливим онтологічним та водночас 


\section{ДИСФУНКЦІОНАЛЬНИЙ ВПЛИВ \\ РЕКЛАМНО-ІНФОРМАЦІЙНОЇ ДІЯЛЬНОСТІ В СУЧАСНОМУ \\ ЄВРОПЕЙСЬКОМУ ПРОСТОРІ: ПРАВОВІ ТА СОЦАЛЬНІ ЧИННИКИ}

когнітивним стимулом, який обумовлює потреби наукового дослідження правових і соціальних чинників рекламної діяльності, враховуючи існуючі соціальні нерівності між європейськими суспільствами індустріального та постіндустріального типу, які взаємодіють у спільному інформаційному просторі.

Ключові слова: глобалізація, рекламно-інформаційна діяльність, соціологічна теорія реклами, рекламна практика, консьюмеризм, соціальний конфлікт.

Lapina Viktoriia, Candidate of Sociological Scienses, PhD (Social Psyhology), Kyiv Taras Shevchenko National University, Kyiv, Ukraine

Dysfunctional influence of advertising and information activity in the contemporary European space: legal and social factors

The article argues the importance of the sociological study of the dysfunctional influence of advertising as a specilized type of the contemporary European space information activities. Today advertising and information activity has significantly evolutionized as a social communication form. From the simple function of promoting goods and services, advertising has transformed into a powerful industry having penetrated into all the ontological mechanisms of the public life. At the beginning of the XXI century, advertising became an important functional component of the modern information space. According to the social science scholars opinion, modern societies witness a significant increase of globalization advertising practices, grow a direct and hidden institutional influence of advertising on various aspects of the individual and collective actors life. Obviously, the global prevalence of advertising, its progressive internationalization and direct involvement in innovative information technologies serve as an important cognitive incentives for the revision of the established traditional views on advertising and information activities. Taking into account these circumstances, the main objective of this article is to characterize the social and communicative peculiarities of the advertising as an information activity in the contemporary European space, to researsh the dysfunctional influence of the advertising under the identification aspects of the following influence regulative legal and social factors. Within the framework of this article the author comes to the conclusions which reflect the innovative scientific approaches for understanding advertising in a broader context of its comprehension - namely, as a special information activity with both constructive and destructive influences upon the processes of constructing certain individuals and social groups life styles. Also the article argues the globalization process intensification to be the important ontological and cognitive stimulus determining the need for further scientific research of the advertising activity legal and social factors, taking into account existing resource 


\section{ДИСФУНКЦІОНАЛЬНИЙ ВПЛИВ \\ РЕКЛАМНО-ІНФОРМАЦІЙНОЇ ДІЯЛЬНОСТІ В СУЧАСНОМУ \\ ЄВРОПЕЙСЬКОМУ ПРОСТОРІ: ПРАВОВІ ТА СОЦАЛЬНІ ЧИННИКИ}

inequalities between the European industrial and post-industrial societies interacting in the common information space.

Key words: globalization, advertising and informational activity, sociological theory of advertising, advertising practice, consumerism phenomenon, social conflict.

Лапина Виктория Викоровна, кандидат социологических наук, доктор философии в области соцчильной психологии, Киевский национальный университет имени Тараса Шевченка, Киев, Украина

\section{Дисфункциональное \\ влияние \\ рекламно-информационной} деятельности в современном европейском пространстве: правовые и социальные факторы

В статье аргументирована важность социологического исследования дисфункционального влияния рекламно-информационной деятельности в современном европейском пространстве. На современном этапе развития обществ Европы и мира рекламно-информационная деятельность значительно эволюционировала как форма социальной коммуникации. От простой функции продвижения товаров и услуг рекламная деятельность превратилась в мощную индустрию и проникла во все основополагающие онтологические механизмы организации общественной жизни. В нач. XXI в. реклама получила признаки рекламно-информационной деятельности, и стала важным функциональным компонентом современной информационной среды. По мнению ученыхобществоведов, в глобализированном обществе наблюдается значительное усиление глобализации рекламных практик, растет прямое и скрытое институциональное влияние рекламы на различные аспекты жизнедеятельности индивидуальных и коллективных субъектов общественной жизни. Очевидно, что глобальная распространенность рекламы, еe прогрессирующая интернационализация и непосредственная причастность к инновационным информационных технологий служат важными познавательными стимулами для пересмотра устоявшихся традиционных взглядов на рекламно-информационную деятельность. Учитывая указанные обстоятельства, цель статьи охарактеризовать социально-коммуникативные проявления рекламноинформационной деятельности в современном европейском пространстве, и определить особенности дисфункционального влияния рекламы в аспектах идентификации правовых и социальных регулятивных факторов этого влияния. В рамках данной статьи аргументированы выводы, в том что современные научные тенденции направлены на понимание рекламы в более широком контексте еe осмысления, a именно: как информационно-рекламной деятельности, которая оказывает как конструктивное, так и деструктивное влияние на процессы конструирования определенных жизненных стилей 


\section{ДИСФУНКЦІОНАЛЬНИЙ ВПЛИВ \\ РЕКЛАМНО-ІНФОРМАЦІЙНОЇ ДІЯЛЬНОСТІ В СУЧАСНОМУ \\ ЄВРОПЕЙСЬКОМУ ПРОСТОРІ: ПРАВОВІ ТА СОЦАЛЬНІ ЧИННИКИ}

индивидов и социальных групп. Также доказано, что современная интенсификация процесса глобализации является тем важным онтологическим и одновременно когнитивным стимулом, который обусловливает необходимость научного исследования правовых и социальных факторов рекламной деятельности, учитывая существующие социальные неравенства между европейскими обществами индустриального и постиндустриального типа, взаимодействующих в общем информационном пространстве.

Ключевые слова: глобализация, рекламно-информационная деятельность, социологическая теория рекламы, рекламная практика, консьюмеризм, социальный конфликт.

Вступ. На сучасному етапі розвитку суспільств Європи та світу рекламно-інформаційна діяльність значно еволюціонувала як форма соціальної комунікації. Від простої функції просування товарів і послуг рекламна діяльність перетворилася в могутню індустрію та проникла в усі основоположні онтологічні механізми організації суспільного життя. На поч. XXI ст. реклама отримала ознаки рекламно-інформаційної діяльності та стала важливим функціональним компонентом сучасного інформаційного середовища. На думку багатьох вчених-суспільствознавців, зараз спостерігається значне посилення глобалізації рекламних практик, зростає прямий та прихований інституціональний вплив реклами на різні аспекти життєдіяльності індивідуальних і колективних суб'єктів суспільного життя. Проте глобальна поширеність реклами, іiі прогресуюча інтернаціоналізація та безпосередня причетність до інноваційних інформаційних технологій слугують важливими пізнавальними стимулами для перегляду усталених традиційних поглядів на рекламно-інформаційну діяльність як в аспекті досліджень іiі дисфункціонального впливу на способи та стилі людей в європейських суспільствах, так і в аспекті визначення можливостей правової та соціальної регуляції рекламних практик.

Враховуючи зазначені обставини, мета статті - охарактеризувати соціально-комунікативні прояви рекламно-інформаційної діяльності в сучасному європейському просторі та визначити особливості дисфункціонального впливу реклами в аспектах ідентифікації правових i соціальних регулятивних чинників цього впливу.

Виклад основного матеріалу. Починаючи 3 кін. ХХ ст., у зв'язку 3 глобальними соціокультурними трансформаціями реклама стала об'єктом вивчення як зарубіжних, так i українських дослідників. Так у працях Дж. Александера, 3. Баумана, Г. Бенеша, Ж. Бодрійяра. П. Бурдьо, Ф. Джеймісона, Н. Лумана, Л. Склейра, I. Рожкова, В. Королька, Н. Лисиці, 


\section{ДИСФУНКЦІОНАЛЬНИЙ ВПЛИВ \\ РЕКЛАМНО-ІНФОРМАЦІЙНОЇ ДІЯЛЬНОСТІ В СУЧАСНОМУ \\ ЄВРОПЕЙСЬКОМУ ПРОСТОРІ: ПРАВОВІ ТА СОЦАЛЬНІ ЧИННИКИ}

Є. Ромата, I. Чудовської справедливо підкреслена важливість дослідження тенденції розширення сфери соціального впливу реклами. Зокрема, не ставлячи під сумнів питання важливої суспільної значущості реклами, вчені намагаються аргументувати концептуальну позицію, згідно якої феномен сучасної реклами вже не доречно розглядати та інтерпретувати як стимул розвитку торгівлі та практик масового споживання [7, с. 12-14].

Якщо майже до кін. XX ст. реклама намагалася переконати споживачів у корисності, ефективності або надійності продукту що рекламується, то зараз вона намагається зв'язати продукт з уявленнями людей про певний життєвий стиль, тобто її виробники все частіше вважають, що споживачів більш цікавить стиль, а не корисність продукту [9, с. 3-4].

Загалом не ставлячи під сумнів питання важливої суспільної значущості реклами, сучасні вчені у своїх працях намагаються аргументувати концептуальну позицію, згідно якої феномен сучасної реклами вже недоречно розглядати та інтерпретувати як стимул розвитку торгівлі та практик масового споживання. Так, американські соціологи Н. Аберкомбі, С. Хіл та Б. С. Тернер аргументовано доводять, що в XXI ст. реклама суттєво змінює своє цільове $\mathrm{i}$ функціональне призначення - вона реально виступає вже не технологічним засобом пропаганди споживчих якостей різних товарів, а постає як важливий транснаціональний інституціональний чинник конструювання певних життєвих стилів індивідів і соціальних груп. «Якщо майже до кінця XX ст. реклама намагалася переконати споживачів у корисності, ефективності або надійності продукту, що рекламується, то зараз вона намагається зв'язати продукт 3 уявленнями людей про певний життєвий стиль, тобто ії виробники все частіше вважають, що споживачів більш цікавить стиль, а не корисність продукту» [1, c. 273].

Вочевидь, що орієнтація реклами на пропаганду певних інтернаціоналізованих стилів життя, а «не корисності продукту» потребує концептуального осмислення певного кола важливих проблем.

По-перше, надзвичайно важливою постає проблема пояснення причин глобалізації рекламних практик, тобто потребує свого осмислення проблема масштабного поширення (експансії) реклами практично в усіх типах сучасних соціальних систем.

По-друге, потребує нового осмислення конструктивістська суспільна місія реклами, яка і полягає у тому, щоб провокувати та створювати новий інтерес» різних соціальних суб'єктів до різноманітних товарів і послуг, спрямованих на інноваційне оновлення суспільного життя. 


\section{ДИСФУНКЦІОНАЛЬНИЙ ВПЛИВ \\ РЕКЛАМНО-ІНФОРМАЦІЙНӦ̈ ДІЯЛЬНОСТІ В СУЧАСНОМУ \\ ЄВРОПЕЙСЬКОМУ ПРОСТОРІ: ПРАВОВІ ТА СОЦАЛЬНІ ЧИННИКИ}

По-третє, акцент на пристосуванні змісту рекламних повідомлень до «уявлень людей про певний життєвий стиль» не означає вирішення важливого питання мінімізації маніпулятивного впливу реклами на поведінку споживачів.

По-четверте, регулювання рекламно-інформаційної діяльності в правовому полі значно відстає від сучасних рекламних технологій, та не забезпечує захист від маніпулятивного впливу.

Слід також наголосити, що важливим об'єктом сучасних інноваційних досліджень рекламних практик $є$ тенденція гнучкої адаптації змісту рекламних повідомлень до існуючих бажань та запитів більшості людей, що значно посилює дисфункціональний вплив реклами як специфічного джерела соціальної напруженості. Аналізуючи особливості цієї тенденції відомий німецький вчений Г. Бенеш аргументовано доводить, що реклама, в ії сучасному розумінні, значно посилює свій соціальний вплив не тому, що вона провокує створення нових запитів та інтересів людей до запропонованих ринком нових предметів споживання, а тому, що сучасна реклама функціонує в режимі гнучкої адаптації до економічних, політичних і культурних змін, у подальшому розвитку яких зацікавлена більшість людей. Саме тому «основна інтенція сучасної реклами - те, що в той чи інший спосіб уже виявляється в прагненнях публіки, використати легше, ніж створювати новий інтерес» [2, с. 427].

Беручи до уваги процес глобальної інтенсифікації рекламних практик, доцільно констатувати, що наукова розробка дослідницької стратегії ідентифікації функціональної специфіки реклами та змісту інформаційнорекламної діяльності потребує пошуку змістовних відповідей на важливі питання: що є причиною дисфункиіонального впливу в інформаційно-рекламній діяльності на сучасне суспільство?

По-перше, період реформування, в якому знаходиться сучасне суспільство, передбачає переосмислення ролі реклами в соціумі. Людство протягом усієї своєї історії здійснювало рекламну діяльність. На кожному етапі розвитку суспільства реклама реалізовувала, перш за все, свою економічну функцію, а саме: стимулювала виробництво товарів і послуг. Але тільки в XX ст. екстенсивний розвиток реклами, обумовлений виникненням i розвитком електронних 3МI, змусило задуматися не тільки про позитивні економічні результати від застосування реклами, але і про негативні наслідки рекламної комунікації. Перш за все, дані негативні наслідки впливу реклами стосуються відтворення культурної спадщини, ціннісно-орієнтаційної бази членів суспільства. Реклама, надаючи оперативну інформацію в поєднанні з емоційнопсихологічним впливом на людину, набуває все більшого значення для індивіда і суспільства. 


\section{ДИСФУНКЦІОНАЛЬНИЙ ВПЛИВ \\ РЕКЛАМНО-ІНФОРМАЦІЙНОЇ ДІЯЛЬНОСТІ В СУЧАСНОМУ ЄВРОПЕЙСЬКОМУ ПРОСТОРІ: ПРАВОВІ ТА СОЦАЛЬНІ ЧИННИКИ}

По-друге, важливо звернути увагу на протиріччя в правовому полі стосовно рекламно-інформаційної діяльності. Зазначимо, що в правовому полі України визначення місця реклами та інформаційно-рекламної діяльності в системі інформаційної політики держави є доволі аморфним. У Законі України «Про інформацію» вказано, що реклама $є$ специфічним джерелом інформації в системі різноманітних довідково-інформаційних видань. «Основними джерелами інформації довідково-енциклопедичного характеру є: енциклопедії, словники, довідники, рекламні повідомлення та оголошення, путівники, картографічні матеріали, електронні бази та банки даних, архіви різноманітних довідкових інформаційних служб, мереж та систем, а також довідки, що видаються уповноваженими на те органами державної влади та органами місцевого самоврядування, об'єднаннями громадян, організаціями, їх працівниками та автоматизованими інформаційно-телекомунікаційними системами» $[4$, с. 650$]$.

Вочевидь, що таке тлумачення не дає можливості чітко розмежувати рекламну діяльність та рекламну інформацію. На нашу думку, таке розмежування $є$ важливим. Тому доцільно підтримати позицію тих вчених, які аргументовано доводять, що «певна інформація як результат рекламної діяльності фахівця-рекламіста тільки тоді стає інформаційним рекламним повідомленням, коли вона підготовлена особливим чином і доведена та передана аудиторії через канали масової комунікації. Самі формати інформаційних рекламних повідомлень можуть бути різними і залежать від конкретних запитів рекламодавця. Передача ж рекламного повідомлення - це найважливіша сутнісна ознака рекламної діяльності» [8, с. 44-45].

По-третє, поширеність інформаційно-рекламної діяльності певним чином посилює соціальну напруженість у системі соціальної стратифікації українського суспільства. У даному зв'язку, слід погодитися в думкою Н. Лумана, що саме сучасні медіа-інститути $є$ відповідальними за нав'язливу глобальну поширеність рекламних повідомлень, оскільки саме ці інститути, постійно створюючи прецеденти формування нових способів маніпулятивного дратівливого впливу на споживачів, реально забезпечують «безперервну освіту і переробку подразнень» [3, с. 152].

Автор підкреслює, що у сільській місцевості, де найбільш виразно проявляється соціальна й економічна стратифікація населення, реклама травмує людей не тільки обставиною матеріального розшарування, але й психологічно. На цьому тлі комерційна телереклама, що демонструє гарне життя в місті породжує особливо в молоді бажання жити красиво там, де живуть герої рекламних роликів, тим самим руйнуючи цінність культурної спадкоємності, сприяє міграції молоді в мегаполіси в пошуках «гарного життя». Глобальна 


\section{ДИСФУНКЦІОНАЛЬНИЙ ВПЛИВ \\ РЕКЛАМНО-ІНФОРМАЦІЙНОЇ ДІЯЛЬНОСТІ В СУЧАСНОМУ \\ ЄВРОПЕЙСЬКОМУ ПРОСТОРІ: ПРАВОВІ ТА СОЦАЛЬНІ ЧИННИКИ}

реклама відкрито демонструє розшарування суспільства на бідних і заможних, породжує протилежні почуття в телеаудиторії й радіоаудиторії міста та села. 3 одного боку, заздрість до благополучним і забезпеченим, з іншого - повагу до багатства, бажання мати рекламований товар, що є основними мотиваторами породження різних псевдопотреб. Насадження «культу грошей»у прихованій рекламі престижних товарів на телеекрані одночасно поляризує суспільство, оскільки демонстрація багатства одних і зневага до бідності інших в абсолютній більшості випадків породжує двоякі почуття притворного гедонізму та образи за існуючу соціальну несправедливість. Разом із тим примусово формуються орієнтація на фетишизацію грошей, упевненість у тому, що саме «багатство й гроші» важливіше всього в досягненні успіху в житті. На думку українського соціолога М. Шульги, пріоритетним технологічним засобом здійснення такого примусу, є реклама. Примітно, що зростаючий соціальний вплив реклами вчений пояснює шляхом розкриття іiі експансіоністської сутності. «Мораль, ідеологію, і знання в суспільстві споживання підмінює реклама. Вона переслідує людину цілодобово... Реклама не проявляє до вас співчуття, на кожному кроці пропонуючи дорогі для вас речі та послуги, і натякуючи на те, що ваш статус (а в дійсності - гаманець) міг би бути і більш солідним. Майже примусове читання реклами, яке прийшло на зміну читання художньої і професійної літератури, журналів, i навіть газет, стало прикметою наших днів» [6, с. 269-270].

У зв'язку з приведеними вище аргументами, можна зазначити, що саме завдяки інтенсивному поширенню інформаційних рекламних повідомлень відбувається глобалізація самого інституту реклами. На думку відомого дослідника у сфері рекламно-інформаційної діяльності Є. Ромата, «Реклама стає частиною соціального інформаційного середовища, вона дієво сприяє становленню певних стандартів мислення та соціальної поведінки як різних верств населення, так і окремого індивіда. Причому це характерно для більшості країн, а в умовах наростаючої глобалізації і для всього світу» [5, с. 21].

Розглянувши вище зазначене, маємо на меті припустити, що сучасні наукові тенденції спрямовані на розуміння реклами в більш широкому контексті iï осмислення, а саме: як інформаційно-рекламної діяльності, яка чинить як конструктивний, так і деструктивний вплив на процеси конструювання певних життєвих стилів індивідів і соціальних груп.

Вочевидь, що інтенсивне поширення рекламних $\mathrm{i}$ рекламноінформаційних практик у сучасних пострадянських суспільствах (у яких, як добре відомо, більшість населення підтримує свою життєдіяльність на рівні мінімальних споживчих стандартів) чинить деструктивний вплив та спричиняє появу нових форм соціальної нерівності та соціальної напруженості. 


\section{ДИСФУНКЦІОНАЛЬНИЙ ВПЛИВ \\ РЕКЛАМНО-ІНФОРМАЦІЙНОӤ ДІЯЛЬНОСТІ В СУЧАСНОМУ \\ ЄВРОПЕЙСЬКОМУ ПРОСТОРІ: ПРАВОВІ ТА СОЦІАЛЬНІ ЧИННИКИ}

\section{Висновки.}

1. Наведені вище позиції щодо новітніх підходів вчених щодо наукового розуміння феномену інформаційно-рекламної діяльності загалом засвідчують про актуальність наукового дослідження причин глобальної експансії в сучасних рекламних практиках.

2. Слід констатувати, поширеність інформаційно-рекламної діяльності певним чином посилює соціальну напруженість у системі соціальної стратифікації українського суспільства, сприяє глобальному утвердженню ідеології консьюмеризму, яка стає засобом маніпуляції масовою свідомістю. Проте реклама пливає на суспільство неоднозначно. Одну частину суспільства цей інститут стимулює покращувати свій стиль і спосіб життя, тоді як інших людей - долучатися до шкідливих звичок, демонструє ознаки формування суспільства споживання. Інформаційно-рекламна діяльність у постсоціалістичних суспільствах Свропи та сучасному українському суспільстві, у яких більшість населення підтримує свою життєдіяльність на рівні мінімальних споживчий стандартів, реально спричиняє появу нових форм соціальної нерівності та соціальної напруженості. Ці процеси певною мірою мають усі шанси стати важливою причиною посилення впливу деструктивних конфліктогенних форм соціальної напруженості.

3. Також доведено, що сучасна інтенсифікація процесу глобалізації є тим важливим онтологічним i водночас когнітивним стимулом, який обумовлює потреби наукового дослідження правових та соціальних чинників рекламної діяльності, враховуючи існуючі соціальні нерівності між європейськими суспільствами індустріального та постіндустріального типу, які взаємодіють у спільному інформаційному просторі.

\section{Список використаних джерел:}

1. Аберкомби Н. Социологический словарь / Н. Аберкомби, С. Хилл, Б. Тернер ; пер с англ. ред. С. А. Ерофеева. - Казань : КГУ, 1997. - 420 с.

2. Бенеш Г. Психологія: dtv-Atlas : довідник : пер з нім. / Г. Бенеш ; наук. ред. пер. О. Васютинський. - Київ : Знання-Прес, 2007. - 510 с.

3. Луман Н. Глобализация мирового сообщества: как следует понимать современное общество / Н. Луман // Социология на пороге XXI века: Новые направления исследования. - Москва : Интеллект, 1998. - С. 94-109.

4. Про інформацію : Закон України // Відомості Верховної Ради України. - 1992. - № 48. - С. 650 .

5. Ромат Е. Реклама : учебник для вузов / Е. Ромат, Д. Сендеров. 9-е изд. - Санкт-Петербург : Питер, 2016. - 54 с. - (Стандарт третьего поколения). 
6. Шульга М. О. Дрейф на узбіччя. Двадцять років суспільних змін в Україні / М. О. Шульга. - Київ : Друкарня Бізнесполіграф, 2011 - 448 с

7. Advertising Theory / ed. by Shelly Rogers, Ester Thorson. - New York : Routledge, 2012. $-610 \mathrm{p}$.

8. De Mooij M. Global marketing and advertising: understending cultural paradoxes / M. De Mooij. - 3 ed. - Sousand Oaks CA : Sage 2010. - 260 p.

9. Thorson E. Advertising Age: the principles of advertising and marketing communications at work / E. Thorson, M. Duffy. - Masson : South-Western publ, 2012. -178 p.

\section{References:}

1. Aberkombi, N. (1997). Sociological dictionary. Translated from English by S.A. Erofeeva. Kazan : Kazan State University.

2. Benesh, H. (2007). Psychology: dtv-Atlas : a guide. Kyiv : Znannia-Pres.

3. Luman, N. (1998). Globalization of the world community: how to understand modern society. V: Sociology at the edge of the XXIst century: New directions of research. Moscow : Intellekt Москва, pp. 94-109.

4. The Law of Ukraine On Information. (1992). Vidomosti Verkhovnoi Rady Ukrainy [Information from the Verkhovna Rada of Ukraine], no. 48, p. 650.

5. Romat, E. (2016). Advertising: a textbook for universities. $9^{\text {th }}$ ed. St. Petersburg : Piter, 2016.

6. Shulha, M.O. (2011). Drift on the roadside. Twenty years of social change in Ukraine. Kyiv : Biznespolihraf Print House.

7. Rogers, Sh., Thorson, E. Eds. (2012). Advertising Theory. New York : Routledge.

8. De Mooij, M. (2010). Global marketing and advertising: understending cultural paradoxes. 3 ed. Sousand Oaks CA : Sage.

9. Thorson, E. (2012). Advertising Age: the principles of advertising and marketing communications at work. Masson : South-Western publishing.

(C) Лапіна В. В., 2018 